\title{
Drikker du mer enn legen din?
}

Aforismen om at du drikker for mye hvis du drikker mer enn legen din, skaper alltid latter i salen under forelesninger. Men ligger det alvor bak uttrykket - drikker egentlig leger for mye? Legeforeningens forskningsinstitutt har kartlagt forbruket av alkohol blant norske leger i mer enn 30 år (1). Resultatene viser at leger ikke drikker mer enn normalbefolkningen. Legers alkoholkonsum ser dessuten ut til å ha utviklet seg i en mer positiv retning enn befolkningens, slik at leger heller drikker mindre enn andre. Det er uvisst hva som ligger bak denne utviklingen. Leger drakk like fullt i gjennomsnitt mer alkohol i 2010 enn i 2000, dog var de sjeldnere beruset (2).

Et mønster som innebærer å drikke alkohol ofte, men i moderate mengder, omtales som «modernisert» og ses oftere hos personer med høyere utdanning enn hos andre (3). Hvorvidt et slikt moderat alkoholkonsum kan betraktes som sunt, har naturlig nok skapt mye debatt. Läkartidningen publiserte tidligere i år en kritisk gjennomgang av forskningsmetodene som har vært brukt for å studere helseeffekter av et moderat konsum (4). Forfatterne levner liten tvil i studiens konklusjon - grunnlaget for å hevde at alkohol har positive helsegevinster, er svakere enn tidligere antatt.

Men ikke alle forskere ender opp med Andréasson og medarbeideres fortolkning. Noen antyder for eksempel at personer som har høyere utdanning og et moderat alkoholforbruk samt sunne levevaner - en gruppe vi kan anta at mange leger identifiserer seg med ser ut til å ha lavere risiko enn avholdsfolk for å dø av hjertesykdom (5). Andre kan igjen vise til at ett til to glass om dagen reduserer risikoen for iskemiske hjerneslag, men ikke for intracerebrale blødninger eller subdurale hematomer (6). I samme studie ble for øvrig mer enn to enheter om dagen klassifisert som høyt alkoholinntak og var forbundet med økt risiko for alle typer slag og hjerneblødninger.

De helseskadelige effektene av høyt alkoholforbruk er uansett udiskutable (7). Av samtlige rusmidler er det alkoholen som gir flest helseskader. Samtidig er alkohol et vanskelig rusmiddel å forholde seg til kanskje først og fremst fordi de fleste av oss er «brukere» i større eller mindre grad. Andréasson og medarbeidere anbefaler høyere priser og lavere tilgjengelighet (4) - kjente tiltak som kan redusere totalforbruket, men som kan være politisk vanskelige å gjennomføre. Effekten kan også tenkes å være begrenset når det gjelder personer med relativt god økonomi - som for eksempel leger.
Hva så med fremtidens leger? Er det mulig at den høye andelen norske utenlandsstudenter fører til endrede alkoholvaner i den norske legestanden totalt sett? Utenlandsstudenter har et betraktelig høyere forbruk enn de som studerer i Norge, men det ser ikke ut til at de tar med seg drikkevanene hjem (8). Legestudenter som er vant med et høyt alkoholkonsum, kan uansett være tilbøyelige til å ende i miljøer med kolleger som drikker mye og selv fortsette med et tilsvarende høyt inntak. Dette gjelder kanskje særlig i kirurgiske fag, der man har sett at kirurgene som gruppe har et mer risikofylt drikkemønster enn andre spesialister (9).

Det nærmer seg jul, en høytid mange forbinder med god mat og godt drikke. Derfor kan julen også forsterke problematiske drikkemønstre. Det må vi fortsette å ta på alvor både som leger og kolleger. Hvorvidt et moderat alkoholinntak kan være positivt for helsen, har vi ennå ikke fått svar på. Mens vi venter på svaret, ser det ut til at jeg må finne nye aforismer å underholde studentene mine med.

\section{Litteratur}

1. Gulbrandsen P. Aasland OG. Endringer i norske legers alkoholvaner 1985-2000 Tidsskr Nor Lægeforen 2002; 122: 2791-4

2. Rosta J, Aasland OG. Changes in alcohol drinking patterns and their consequences among Norwegian doctors from 2000 to 2010: a longitudinal study based on national samples. Alcohol Alcohol 2013; 48: 99-106.

3. Rosta J. Legers alkoholvaner i endring. Tidsskr Nor Legeforen 2015; 135: 1483

4. Andréasson S, Chikritzhs T, Dangardt F et al. Måttlig alkohol-konsumtion ger ingen positiv hälsoeffekt - En kritisk forskningsanalys. Läkartidningen 2016 113

5. Ronksley PE, Brien SE, Turner BJ et al. Association of alcohol consumption with selected cardiovascular disease outcomes: a systematic review and metaanalysis. BMJ 2011; 342: d671.

6. Larsson SC, Wallin A, Wolk A et al. Differing association of alcohol consumption with different stroke types: a systematic review and meta-analysis. BMC Med 2016; 14: 178.

7. Legeforeningen. Alkohol er vårt største rusmiddelproblem. Tidsskr Nor Legeforen 2006; 126: 1809.

8. Aasland OG. Wiers-Jenssen J. Norske medisinstudenter i utlandet - karriereplaner, personlighet, røyking og alkoholbruk. Tidsskr Nor Lægeforen 2001; 121: 1677-82.

9. Rosta J, Aasland OG. Female surgeons' alcohol use: a study of a national sample of norwegian doctors. Alcohol Alcohol 2005; 40: 436-40. 